\title{
Strontium isotope stratigraphy of the Pelotas Basin
}

\author{
Estratigrafia de isótopos de estrôncio da Bacia de Pelotas \\ Geise de Santana dos Anjos Zerfass ${ }^{1 *}$, Farid Chemale Jr. ${ }^{2}$, \\ Candido Augusto Veloso Moura ${ }^{3}$, Karen Badaraco Costa ${ }^{4}$, Koji Kawashita ${ }^{5}$
}

\begin{abstract}
Strontium isotope data were obtained from foraminifera shells of the Pelotas Basin Tertiary deposits to facilitate the refinement of the chronostratigraphic framework of this section. This represents the first approach to the acquisition of numerical ages for these strata. Strontium isotope stratigraphy allowed the identification of eight depositional hiatuses in the Eocene-Pliocene section, here classified as disconformities and a condensed section. The reconnaissance of depositional gaps based on confident age assignments represents an important advance considering the remarkably low chronostratigraphic resolution in the Cenozoic section of the Pelotas Basin. The recognition of hiatuses that match hiatuses is based on biostratigraphic data, as well as on global events. Furthermore, a substantial increase in the sedimentation rate of the upper Miocene section was identified. Paleotemperature and productivity trends were identified based on oxygen and carbon isotope data from the Oligocene-Miocene section, which are coherent with worldwide events, indicating the environmental conditions during sedimentation.
\end{abstract}

KEYWORDS: foraminifera; Pelotas Basin; strontium isotopes; stable isotopes; Paleogene; Neogene.
RESUMO: Dados da razão isotópica de estrôncio foram obtidos a partir da análise de conchas de foraminiferos recuperadas dos depósitos terciários da Bacia de Pelotas visando o refinamento do arcabouço cronoestratigráfico dessa seção. Este artigo representa a primeira abordagem à obtenção de idades numéricas para esses estratos. A estratigrafia de isótopos de estrôncio permitiu a identificação de oito hiatos deposicionais na seçấo Eoceno-Plioceno, aqui classificados como desconformidade, além de uma seçâo condensada. O reconhecimento de hiatos deposicionais representa um importante avanço, considerando a baixa resolução cronoestratigráfica da seção cenozóica da Bacia de Pelotas. Além disso, foi identificado um substancial aumento na taxa de sedimentação na seção neomiocênica. Tendências gerais de paleotemperatura e produtividade foram identificadas com base em dados das razóes isotópicas de oxigênio e carbono da seção Oligoceno-Mioceno. Essas tendências são coerentes com eventos globais, evidenciando as condiçōes ambientais durante a sedimentação..

PALAVRAS-CHAVE: foraminiferos; Bacia de Pelotas; isótopos de estrôncio; isótopos estáveis; Paleogeno; Neogeno. 


\section{INTRODUCTION}

The Pelotas Basin is a marginal basin filled by sediments deposited during different stages of the South Atlantic Ocean opening. The Tertiary section represents the sedimentation during a regressive period that was repeatedly interrupted, allowing the formation of disconformities surfaces. Deposits of this age in the Brazilian continental margin became an important target for exploration due to the occurrence of hydrocarbon reserves, including giant oil and gas fields in the Santos and Campos basins.

Although several authors have focused their studies in the Pelotas Basin (e.g. Fontana 1990, 1996; Abreu 1998; Rosa 2007; Castillo et al. 2009; Contreras et al. 2010; Stica et al. 2014), only sparse estimations of age obtained from biostratigraphic studies are available (Gomide 1989, Coimbra et al. 2009; Guerra et al. 2012). The absence of volcanic rocks suitable for geochronological analysis and the abundance of calcareous microfossils in the dominant siliciclastic sedimentary rocks present a favorable scenario for the use of strontium isotope data to obtain chronostratigraphic data for the Paleogene-Neogene section of the Pelotas Basin.

The use of strontium isotopic ratio variations through time as a dating method allows accurate relative age determinations. The best resolution obtained from this method was registered at steeped segments of the standard curve as particular segments of the Cenozoic including Neogene and Paleocene, with the best temporal resolution from late Eocene to middle Miocene and from late Pliocene to Pleistocene (Elderfield 1986; Hess et al. 1986; Hodell et al. 1991; Hodell \& Woodruff 1994; Oslick et al. 1994). Previous applications of ${ }^{87} \mathrm{Sr} /{ }^{86} \mathrm{Sr}$ ratio data in Tertiary sediments were presented by Depaolo and Finger (1991), Sugarman et al. (1993), Lavelle (2000), Ehrenberg et al. (2007), and Parras et al. (2012), which achieved suitable results in terms of age constraints.

This study seeks to present a chronostratigraphic framework based on the Sr-isotope relative ages for the Pelotas Basin Tertiary deposits obtained from foraminiferal shells analyses. Additionally, condensed sections and depositional gaps were identified. Major climatic and paleoproductivity were also related to the interval studied.

\section{GEOLOGICAL SETTING}

The Pelotas Basin corresponds to the South America continental margin between $28^{\circ} 40^{\prime} \mathrm{S}$ and $34^{\circ} \mathrm{S}$, limited at north by the Florianópolis High (Brazil) and at south by the Polonio High (Uruguay) (Kowsmann et al.1974; Rosa 2007). The basin area is approximately $210,000 \mathrm{~km}^{2}$, from which an area of $40,000 \mathrm{~km}^{2}$ is emerged (Fig. 1). The thickness of the sedimentary column reaches $12,000 \mathrm{~m}$ on the depocenter (Fontana 1996). In terms of structural framework, the Pelotas Basin presents incipient post-depositional deformation, represented by tilted blocks with strata dipping seaward (Fontana 1987; Rosa 2007). The Rio Grande Cone is a 4,000-m-thick depositional feature formed during the Neogene and located in the southern portion of the Pelotas Basin, where there are flat-lying detachments linking normal faults at the top of the slope to thrusts at the bottom.

The basin was partially developed over the continental crust (Pre-Cambrian basement, Gondwana sediments, and basaltic rocks extruded during the pre-rift phase), and the remainder over the oceanic crust floor on its distal portion (Fontana 1990).

The studied interval corresponds to a part of a major Paleocene-Holocene regressive supercycle that encompasses proximal siltstones and sandstones assigned to the Cidreira Formation and mudstones with rare intercalations of turbiditic sands, which are designated as Imbé Formation (Dias et al. 1994; Fontana 1996; Bueno et al. 2007). The Cidreira Formation deposits prograde to the basin distal portions, inter-fingering with the Imbé Formation sediments. In the late Paleocene, deposition of the regressive section is characterized by prograding clastic wedges with increasing sedimentary input.

\section{MATERIALS AND METHODS}

The studied material consists of foraminiferal shells recovered from cutting and core samples collected from three offshore wells drilled by Petrobras in the Pelotas Basin (Fig. 1). The studied sections consist of shales with intercalations of marls, siltstones, and sandstones (Fig. 2).

The ${ }^{87} \mathrm{Sr} /{ }^{86} \mathrm{Sr}$ ratio was obtained from 103 cutting samples taken from two drill-holes (PEL-1A and PEL-2A) from which 18 samples were collected in the drill-hole PEL-1A (from 2,142 to 3,708 $\mathrm{m}$ ) and 85 samples were collected from drill-hole PEL-2A (from 720 to 2,619 m) (Fig. 2). In addition, three core samples $(1,300,1,303.6$, and 1,304.05 m) from drill-hole 2-RSS-1, composed of grayish shales containing abundant calcareous microfossils, were analyzed.

The sample preparation followed the conventional micropaleontological techniques for calcareous microfossils. Foraminiferal shells were separated from the bulk sediment by hand-picking under a stereomicroscope Olympus-SZ1145 and, subsequently, well-preserved shells were selected for isotopic analysis.

Selection of foraminiferal shells involved inspection under a stereomicroscope. The selected shells do not present evidences of dissolution, recrystallization, overgrowths, or internal filling. Only in the top of the studied sections glassy 


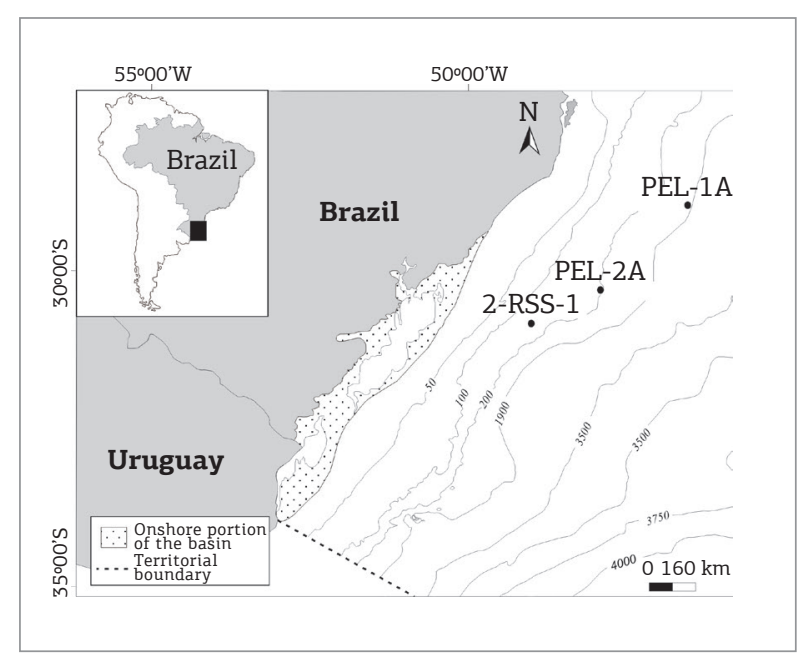

Figure 1. Location map of the Pelotas Basin with the situation of the studied drill-holes.

foraminifera were found. Along the section, the selected planktonic shells had a frosty appearance and were assumed to be well-preserved. Planktonic foraminiferal tests are generally more sensitive to post-depositional alterations than benthic ones due to its densely perforated wall. Shells of living planktonic foraminifera have a glassy appearance under the stereomicroscope. However, this type of preservation is unusual among assemblages of deep-sea sediments and fossil planktonic foraminifera tests are mostly frosty, indicating a minor degree of diagenetic alteration (Pearson et al. 2001).

Among the selected specimens from the fraction $>150 \mu \mathrm{m}$, some were separated and submitted to scanning electronic microscope imaging to confirm the wall preservation because diagenetic alterations can occur in micrometer scale (Sexton et al. 2006; Williams et al. 2007).

The ultrastructure preservation assessment was made to guarantee the selection of preserved material for analytical purposes, as post-depositional alterations could lead to misinterpretations (Lohmann 1995; Brown \& Elderfield 1996; Shieh et al. 2002).

The selected specimens were crushed under ultrapure water (Milli-Q) and then ultrasonically washed with ultrapure water. ${ }^{87} \mathrm{Sr} /{ }^{86} \mathrm{Sr}$ ratio analyses were carried out at the Isotopic Geology Laboratory of the Federal University of Rio Grande do Sul, Brazil. The samples were dissolved in $500 \mathrm{~mL}$ of 5 $\mathrm{N} \mathrm{HNO}_{3}$ for 60 minutes at $60^{\circ} \mathrm{C}$ and then centrifuged for 10 minutes and dried at $120^{\circ} \mathrm{C}$. Subsequently, the samples were dissolved in $250 \mathrm{~mL}$ of $5 \mathrm{~N} \mathrm{HNO}_{3}$.

Strontium was extracted using a mixture of SrSpec ${ }^{\mathrm{TM}}$ resin, $5 \mathrm{~N}$ ultrapure $\mathrm{HNO}_{3}$, and Milli-Q water and then collected in a mixture of Milli-Q water with $7 \mathrm{~N} \mathrm{HNO}_{3}$ and $\mathrm{H}_{3} \mathrm{PO}_{4}$. Samples were loaded on rhenium filaments with $2 \mathrm{~mL}$ of $\mathrm{H}_{3} \mathrm{PO}_{4}$ and $1 \mathrm{~mL}$ of $\mathrm{TaCl}_{5}$.

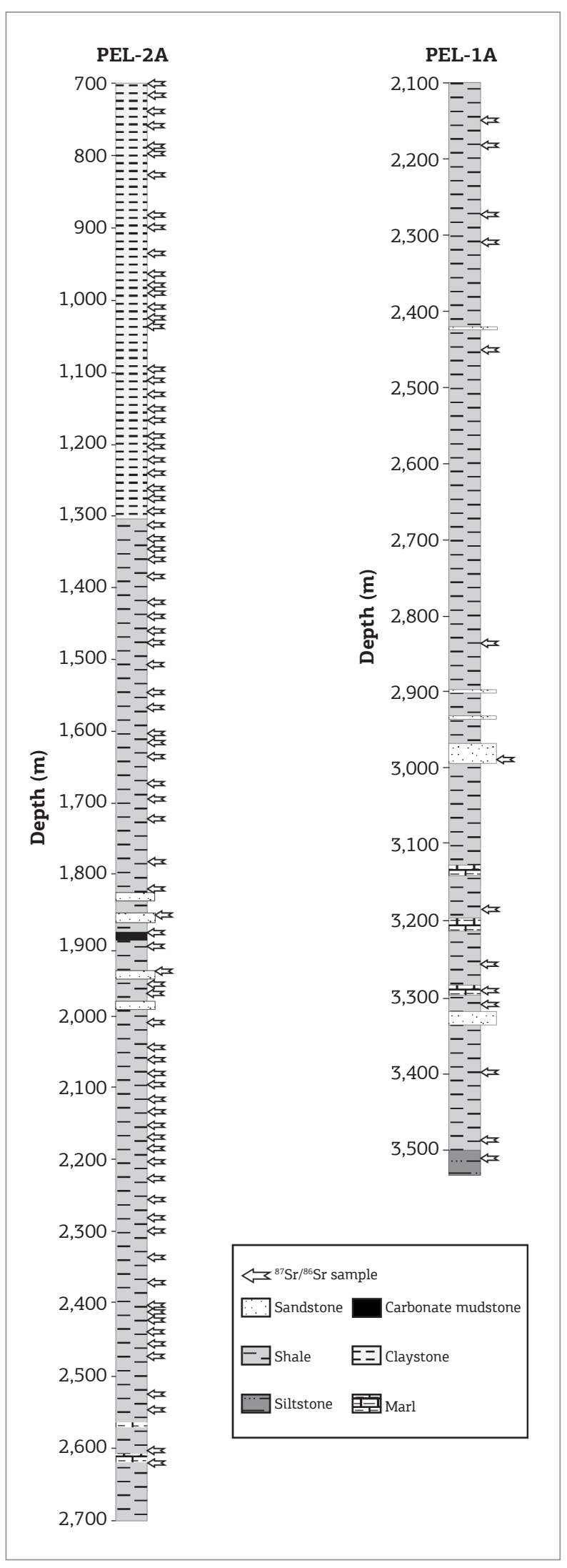

Figure 2. Lithological logs of drill-holes $1 \mathrm{~A}$ and $2 \mathrm{~A}$ and indication of the sampling points for strontium ratio analyses. 
Isotopic ratios were measured in dynamic mode with a VG Sector 54 multi-collector mass spectrometer. An average of $100-120$ ratios was collected with a 1 -volt ${ }^{88} \mathrm{Sr}$ beam. Strontium ratios were normalized to ${ }^{87} \mathrm{Sr} /{ }^{86} \mathrm{Sr}=0.1194$. Analyses were adjusted for instrumental bias arising due to periodic adjustment of the collector positions as monitored by laboratory internal standards. The mass discrimination effect was corrected by the conventional internal correction technique, which provides the radiogenic ${ }^{87} \mathrm{Sr} /{ }^{86} \mathrm{Sr}$ isotopes ratios using the non-radiogenic ${ }^{86} \mathrm{Sr} /{ }^{88} \mathrm{Sr}$ isotopic ratios as 0.1194 (Nier 1938). The adjustment of analyses was based on instrumental bias and the reported values were previously corrected. During the period in which the samples were evaluated, 14 standards were analyzed.

Measurements for the NIST SRM 987 standard were ${ }^{87} \mathrm{Sr} /{ }^{86} \mathrm{Sr}=0.710250 \pm 0.000007$. The average for all blanks was $<30 \mathrm{pg} / \mathrm{g}$ of strontium. Blank correction for strontium isotopic compositions was insignificant.

Strontium and calcium concentrations were determined with ICP-MS by Activation Laboratories Ltd., Ontario, Canada. Sr/Ca ratios were also used to evaluate the preservation of the original composition of the shells. The number of specimens selected to evaluate strontium and calcium concentrations varied from 2 to 15 specimens per sample depending on specimen size. A total of 75 samples were analyzed, from which 32 samples were from drill-hole PEL-2A, 31 samples were from drill-hole PEL-1A, and 12 samples were from the 2-RSS-1 drill-hole. The samples were dissolved in aqua regia at $90^{\circ} \mathrm{C}$ for two hours. The solution was diluted and analyzed using an ICP/MS 6000 that provides a detection limit of $0.5 \%$ for strontium and $0.01 \%$ for calcium.

Carbon and oxygen isotopic analyses were performed in 36 samples from the drill-hole PEL-2A at the Isotope Geology Laboratory of the Federal University of Pará, Brazil. The number of test samples varied from 2 to 6 per sample depending on the size of specimens.

$\mathrm{CO}_{2}$ gas was extracted from the foraminiferal tests using $100 \%$ orthophosphoric acid at $70^{\circ} \mathrm{C}$. The gas was analyzed using an online KIEL-III system coupled to the mass spectrometer Finnigan MAT-252. The results obtained are reported in the conventional $\mathrm{d}$ notation in per mil (\%o) relative to Chicago PDB standard. Analysis of the standard NBS-19 during this study presented average values of $\delta^{13} \mathrm{C}$ and $\delta^{18} \mathrm{O}$ of 2.0 and $-2.13 \%$ PDB, respectively.

\section{RESULTS}

Well-preserved foraminiferal shells were selected through observation under the stereomicroscope. To assure the selection of well-preserved shells some of the previously selected specimens were separated to proceed for $\mathrm{Sr} / \mathrm{Ca}$ ratio analysis. The $\mathrm{Sr} / \mathrm{Ca}$ ratios ranged from $0.70 \mathrm{mmol} \mathrm{mol}^{-1}$ to $2.29 \mathrm{mmol} \mathrm{mol}^{-1}$ (Table 1). These data are consistent with the range of Sr/Ca ratios recorded for Recent-to-Eocene Atlantic Ocean foraminifera shells and carbonates compiled from the literature (Hampt \& Delaney 1997; Lea et al. 1999; Lear et al. 2003; Hall \& Chang 2004). These data indicate a good preservation of the foraminiferal shells in the studied samples.

It is worth mentioning that along the studied drill-holes, foraminiferal shells presenting evident contaminant phases and/or dissolution features were observed. A study of the post-depositional features observed in foraminiferal tests in the Miocene section of the same wells had been presented by Anjos-Zerfass et al. (2011).

In the drill-hole PEL-2A, ${ }^{87} \mathrm{Sr} /{ }^{86} \mathrm{Sr}$ values range from 0.707660 to 0.708850 and standard deviation (2s) ranges from 0.000014 to 0.000128 (Appendix 1). The ${ }^{87} \mathrm{Sr} /{ }^{86} \mathrm{Sr}$ ratio obtained from the drill-hole PEL-1A samples oscillated between 0.707069 and 0.709209 , and values of 2 s ranged from 0.000011 to 0.000058 (Appendix 2). The strontium ratio from the core of the drill-hole 2-RSS-1 samples varied from 0.708766 to 0.708697 and 2 s ranged from 0.000028 to 0.000050 (Appendix 2).

The standard curve used for age assessment was derived from the database compiled by McArthur et al. (2001) and McArthur and Howarth (2004). The chronology is based on the International Commission of Stratigraphy Time Table 2012.

The estimated ages for well PEL-1A range from 14.9 to 34.15 Ma, and the section of drill-hole PEL-2A spans from 3.7 to $54.41 \mathrm{Ma}$. In drill-hole 2 -RSS- $1,{ }^{87} \mathrm{Sr} /{ }^{86} \mathrm{Sr}$ relative ages range from 15.28 to $16.60 \mathrm{Ma}$ (Fig. 3). Ages older than $40 \mathrm{Ma}$ should be considered with caution due to the scatter in the dataset and the small amount of samples analyzed. Moreover, the segment of the reference curve between 40 and $55 \mathrm{Ma}$ is less steeped and, consequently, provides a lower temporal resolution.

The distribution of the estimated ages throughout the studied wells facilitated the identification of depositional gaps and the estimation of sedimentation rates.

Two hiatuses were identified in the studied section of drill-hole PEL-1A: (i) late Oligocene (Chattian, 24.45 Ma) to early Miocene (Aquitanian, 22.70 Ma) at 3,402 m and (ii) early to middle Miocene (Burdigalian to Langhian, 17.8 - $14.9 \mathrm{Ma}$ ) at 2,142 m (Fig. 4).

Six hiatuses were recognized in the sampled section of drillhole PEL-2A: (i) early Eocene (Ypresian, 50.47 - 48.88 Ma) at $2,547 \mathrm{~m}$, (ii) late Eocene to early Oligocene (BartonianRupelian, 40.6 - 33.65 Ma) at 2,259 m, (iii) early Oligocene (Rupelian, $32.38-30.65 \mathrm{Ma}$ ) at 2,187 m, (iv) early to late Oligocene (Rupelian-Chattian, ca. 28 - 25.6 Ma) at 2,061 m, (v) middle to late Miocene (Langhian-Tortonian, 
Table 1. Sr/Ca ratio data (mmol.mol-1)

\begin{tabular}{|c|c|c|c|c|c|c|c|c|}
\hline Drill-hole & $\begin{array}{l}\text { Depth } \\
\text { (m) }\end{array}$ & $\begin{array}{c}\mathrm{Sr} / \mathrm{Ca} \\
\mathrm{mmol} \mathrm{mol}^{-1}\end{array}$ & Drill-hole & $\begin{array}{l}\text { Depth } \\
\text { (m) }\end{array}$ & $\begin{array}{c}\mathrm{Sr} / \mathrm{Ca} \\
\mathrm{mmol} \mathrm{mol}^{-1}\end{array}$ & Drill-hole & $\begin{array}{l}\text { Depth } \\
\text { (m) }\end{array}$ & $\begin{array}{c}\mathrm{Sr} / \mathrm{Ca} \\
\mathrm{mmol} \mathrm{mol}^{-1}\end{array}$ \\
\hline PEL-2A & 1,044 & 1.21 & PEL-2A & 2,331 & 2.29 & PEL-1A & 3,186 & 0.88 \\
\hline PEL-2A & 1,098 & 1.34 & PEL-2A & 2,529 & 1.59 & PEL-1A & 3,258 & 0.88 \\
\hline PEL-2A & 1,098 & 1.30 & PEL-2A & 2,529 & 1.62 & PEL-1A & 3,276 & 0.79 \\
\hline PEL-2A & 1,116 & 1.40 & PEL-2A & 2,547 & 1.56 & PEL-1A & 3,312 & 0.84 \\
\hline PEL-2A & 1,134 & 1.62 & PEL-2A & 2,601 & 1.17 & PEL-1A & 4,104 & 1.32 \\
\hline PEL-2A & 1,170 & 1.36 & PEL-1A & 2,142 & 1.04 & PEL-1A & 4,140 & 1.23 \\
\hline PEL-2A & 1,188 & 1.30 & PEL-1A & 2,178 & 1.20 & PEL-1A & 4,230 & 1.11 \\
\hline PEL-2A & 1,224 & 1.36 & PEL-1A & 2,178 & 1.04 & PEL-1A & 4,338 & 1.00 \\
\hline PEL-2A & 1,242 & 1.38 & PEL-1A & 2,214 & 1.36 & PEL-1A & 4,356 & 1.05 \\
\hline PEL-2A & 1,260 & 1.35 & PEL-1A & 2,232 & 1.31 & 2-RSS-1 & $1,300.8$ & 1.60 \\
\hline PEL-2A & 1,296 & 1.50 & PEL-1A & 2,304 & 1.40 & 2-RSS-1 & $1,301.15$ & 2.01 \\
\hline PEL-2A & 1,314 & 1.34 & PEL-1A & 2,340 & 1.32 & 2-RSS-1 & $1,301.75$ & 0.94 \\
\hline PEL-2A & 1,332 & 1.34 & PEL-1A & 2,376 & 1.36 & 2-RSS-1 & $1,302.25$ & 1.47 \\
\hline PEL-2A & 1,332 & 1.29 & PEL-1A & 2,412 & 1.47 & 2-RSS-1 & $1,303.60$ & 1.49 \\
\hline PEL-2A & 1,350 & 1.39 & PEL-1A & 2,484 & 1.61 & 2-RSS-1 & $1,304.05$ & 1.39 \\
\hline PEL-2A & 1,368 & 1.23 & PEL-1A & 2,448 & 1.35 & 2-RSS-1 & $1,305.55$ & 1.48 \\
\hline PEL-2A & 1,386 & 1.34 & PEL-1A & 2,592 & 1.35 & 2-RSS-1 & $1,306.10$ & 1.55 \\
\hline PEL-2A & 1,440 & 1.83 & PEL-1A & 2,628 & 1.18 & 2-RSS-1 & $1,306.10$ & 2.06 \\
\hline PEL-2A & 1,440 & 0.70 & PEL-1A & 2,664 & 1.24 & 2-RSS-1 & $1,307.10$ & 1.56 \\
\hline PEL-2A & 1,476 & 1.32 & PEL-1A & 2,700 & 1.34 & 2-RSS-1 & $1,308.55$ & 1.94 \\
\hline PEL-2A & 1,512 & 1.59 & PEL-1A & 2,700 & 1.32 & 2-RSS-1 & $1,308.55$ & 1.47 \\
\hline PEL-2A & 1,818 & 1.28 & PEL-1A & 2,736 & 1.32 & & & \\
\hline PEL-2A & 2,097 & 1.42 & PEL-1A & 2,772 & 1.03 & & & \\
\hline PEL-2A & 2,115 & 1.13 & PEL-1A & 2,962 & 1.02 & & & \\
\hline PEL-2A & 2,187 & 1.33 & PEL-1A & 3,114 & 0.98 & & & \\
\hline PEL-2A & 2,223 & 0.94 & PEL-1A & 3,132 & 0.78 & & & \\
\hline PEL-2A & 2,295 & 1.09 & PEL-1A & 3,168 & 0.88 & & & \\
\hline
\end{tabular}

14.94-11.4 Ma) at 1,350 $\mathrm{m}$, and (vi) late Miocene (TortonianMessinian, 8.65 - 5.7 Ma) at $978 \mathrm{~m}$ (Fig. 4).

The ages obtained from drill-hole 2-RSS-1 indicate a hiatus in the early Miocene (Burdigalian, 16.5 - 15.28 Ma) at $1,301.17 \mathrm{~m}$.

Stable isotope data obtained from drill-hole PEL-1A ranged from -1.56 to $3.01 \%$ and between -1.25 and $2.58 \%$ o for oxygen and carbon, respectively. In drill-hole PEL-2A, values of $\delta^{18} \mathrm{O}$ ratio ranged from -1.59 to $1.86 \%$ and $\delta^{13} \mathrm{C}$ ratio varied between -1.77 and $2.31 \%$ (Tab. 2).

\section{DISCUSSION}

\section{Post-depositional/burial processes}

Sample preservation was assessed by evaluating shells' microstructure using scanning electronic microscope imaging, $\mathrm{Sr} / \mathrm{Ca}$ ratio, and carbon and oxygen isotope analyses. The studied samples' Sr/Ca ratios values match with the range of values recorded for Tertiary deposits foraminifera shells from the South Atlantic, indicating the preservation of the shells' original composition. 


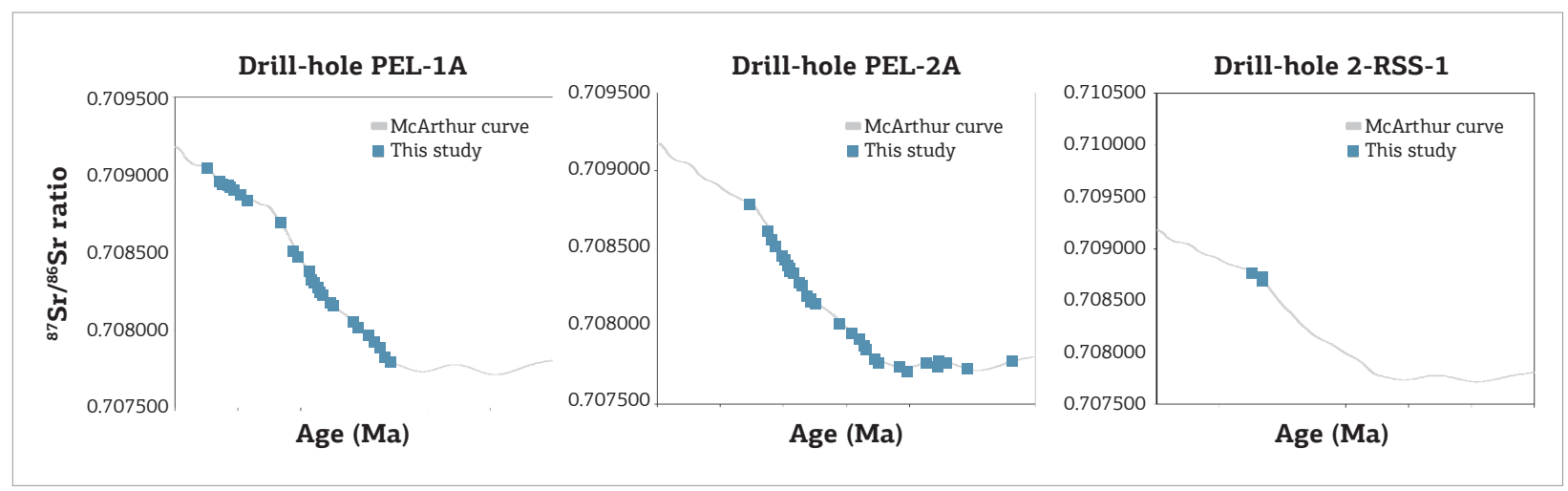

Figure $3 .{ }^{87} \mathrm{Sr} /{ }^{86} \mathrm{Sr}$ ratio data of drill-holes PEL-1A and PEL-2A and the corresponding relative ages.

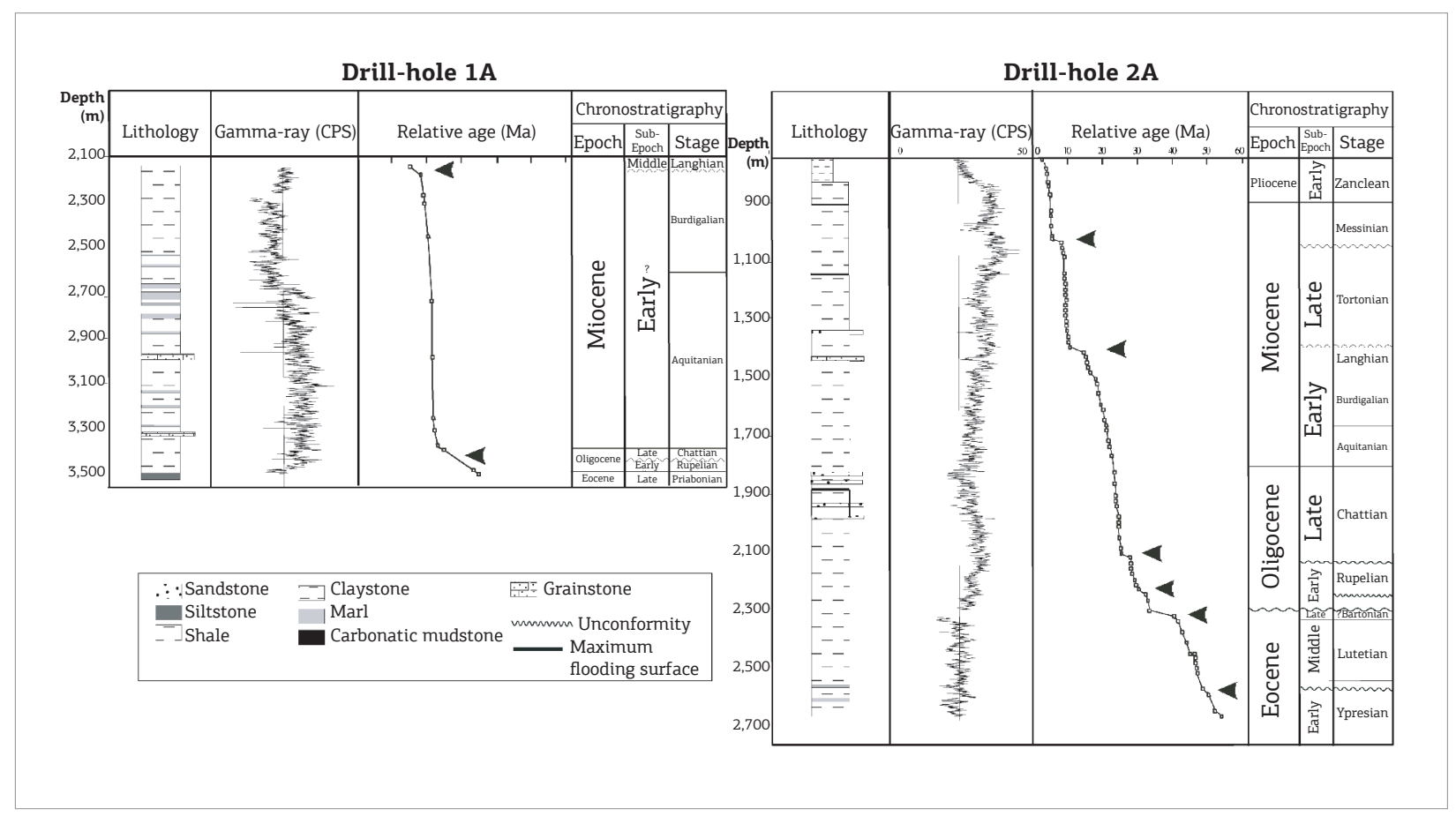

Figure 4. Hiatuses identified in the section of drill-holes PEL-1A and PEL-2A.

Most of the $\delta^{18} \mathrm{O}$ and $\delta^{13} \mathrm{C}$ data acquired for the studied section correspond to average values referred to in the literature for Tertiary carbonates as confirmed in the compilation presented by Veizer et al. (1999). The $\delta^{18} \mathrm{O}$ values do not co-vary with $\delta^{13} \mathrm{C}$ values (Fig. 5), representing evidence of original isotopic composition preservation of most studied samples.

The group of samples presenting lighter and scattered $\delta^{18} \mathrm{O}$ and $\delta^{13} \mathrm{C}$ values may be related to the replacement of the foraminiferal calcite by isotopically lighter cements. This may be due to the shell's interaction with isotopically lighter water associated with the organic matter oxidation and enrichment of the dissolved carbon in ${ }^{12}$ C (Savin \& Douglas 1973; Scholle \& Arthur 1980; Killingley 1983; Williams et al. 2005).
Shells exhibiting dissolution features were found in drill-hole PEL-2A in an interval dated as late Miocene (9.46-10.35 Ma), whereas in the sampled section of drill-hole PEL-1A, this type of post-depositional alteration was not observed. Dissolution takes place during the interaction of carbonates with water sub-saturated in calcium carbonate (Collen \& Burgess 1979). Accordingly, the partial shell dissolution in the more proximal well PEL-2A may be related to meteoric water infiltration caused by a regressive event, which could be associated with the above-mentioned Tortonian-Messinian hiatus.

Shells presenting an oxidized coating were found in an interval that ranges from Burdigalian to Tortonian in drillhole PEL-2A and in the Burdigalian section of well PEL-1A. The oxidized shell concentration may be related to a regressive 
Table 2. Stable isotope data obtained from the studied samples

\begin{tabular}{|c|c|c|c|c|c|c|c|}
\hline Drill-hole & $\begin{array}{l}\text { Depth } \\
\text { (m) }\end{array}$ & $\begin{array}{c}\delta^{18} \text { O PDB } \\
(\%)\end{array}$ & $\begin{array}{c}\delta^{13} C \text { PDB } \\
(\% \circ)\end{array}$ & Drill-hole & $\begin{array}{l}\text { Depth } \\
\text { (m) }\end{array}$ & $\begin{array}{c}\delta^{18} \mathrm{O} \text { PDB } \\
(\%)\end{array}$ & $\begin{array}{c}\delta^{13} C \text { PDB } \\
(\% \circ)\end{array}$ \\
\hline PEL-2A & 1,008 & 1.86 & 1.12 & PEL-2A & 2,421 & 0.11 & -0.75 \\
\hline PEL-2A & 1,044 & -0.50 & 2.27 & PEL-2A & 2,457 & -0.83 & -1.32 \\
\hline PEL-2A & 1,098 & -0.39 & 1.67 & PEL-2A & 2,529 & -1.41 & -0.17 \\
\hline PEL-2A & 1,116 & 0.57 & 1.53 & PEL-2A & 2,601 & -1.35 & -0.92 \\
\hline PEL-2A & 1,134 & -0.18 & 1.92 & PEL-1A & 2,178 & 2.74 & -1.09 \\
\hline PEL-2A & 1,152 & -0.81 & 1.45 & PEL-1A & 2,214 & 1.55 & 0.27 \\
\hline PEL-2A & 1,170 & -0.47 & 2.23 & PEL-1A & 2,232 & 2.75 & 0.09 \\
\hline PEL-2A & 1,188 & 0.53 & 1.59 & PEL-1A & 2,268 & 3.01 & -0.38 \\
\hline PEL-2A & 1,206 & -0.74 & 2.31 & PEL-1A & 2,340 & 1.33 & 0.01 \\
\hline PEL-2A & 1,224 & 0.58 & 1.28 & PEL-1A & 2,376 & 0.71 & 1.79 \\
\hline PEL-2A & 1,242 & 0.45 & 1.68 & PEL-1A & 2,412 & 0.66 & 1.38 \\
\hline PEL-2A & 1,278 & 0.23 & 1.30 & PEL-1A & 2,448 & -0.01 & 1.00 \\
\hline PEL-2A & 1,296 & 0.12 & 1.43 & PEL-1A & 2,466 & 0.77 & 1.75 \\
\hline PEL-2A & 1,314 & -0.09 & 1.23 & PEL-1A & 2,484 & 0.40 & 1.45 \\
\hline PEL-2A & 1,332 & 0.28 & 1.63 & PEL-1A & 2,502 & 2.32 & -0.04 \\
\hline PEL-2A & 1,350 & 0.53 & 1.01 & PEL-1A & 2,556 & 2.60 & -0.24 \\
\hline PEL-2A & 1,368 & 0.84 & 0.79 & PEL-1A & 2,592 & 2.64 & -0.49 \\
\hline PEL-2A & 1,386 & 0.40 & 1.21 & PEL-1A & 2,628 & 0.67 & 1.92 \\
\hline PEL-2A & 1,440 & 0.83 & 0.12 & PEL-1A & 2,664 & -0.13 & 2.23 \\
\hline PEL-2A & 1,458 & -0.37 & -1.31 & PEL-1A & 2,700 & -0.50 & 2.58 \\
\hline PEL-2A & 1,476 & 0.20 & 0.03 & PEL-1A & 2,736 & -0.38 & 1.82 \\
\hline PEL-2A & 1,512 & -3.37 & 0.09 & PEL-1A & 2,772 & 2.50 & -0.75 \\
\hline PEL-2A & 1,566 & -1.59 & 1.51 & PEL-1A & 2,808 & 0.48 & 1.61 \\
\hline PEL-2A & 1,602 & 0.58 & -1.15 & PEL-1A & 2,862 & -0.89 & 1.62 \\
\hline PEL-2A & 1,638 & -0.41 & 1.89 & PEL-1A & 2,898 & 0.59 & 1.42 \\
\hline PEL-2A & 1,818 & 1.02 & 1.03 & PEL-1A & 2,962 & 0.31 & -0.40 \\
\hline PEL-2A & 2,097 & 1.11 & -0.05 & PEL-1A & 3,024 & 0.61 & -0.34 \\
\hline PEL-2A & 2,115 & 0.01 & -1.77 & PEL-1A & 3,042 & 1.25 & 0.28 \\
\hline PEL-2A & 2,187 & 0.80 & -0.54 & PEL-1A & 3,114 & 1.38 & 0.34 \\
\hline PEL-2A & 2,295 & -0.99 & -1.07 & PEL-1A & 3,186 & -1.20 & -0.80 \\
\hline PEL-2A & 2,331 & -1.36 & -1.72 & PEL-1A & 3,258 & -1.56 & -1.25 \\
\hline PEL-2A & 2,403 & -0.62 & -1.46 & PEL-1A & 3,276 & -1.01 & 0.06 \\
\hline
\end{tabular}



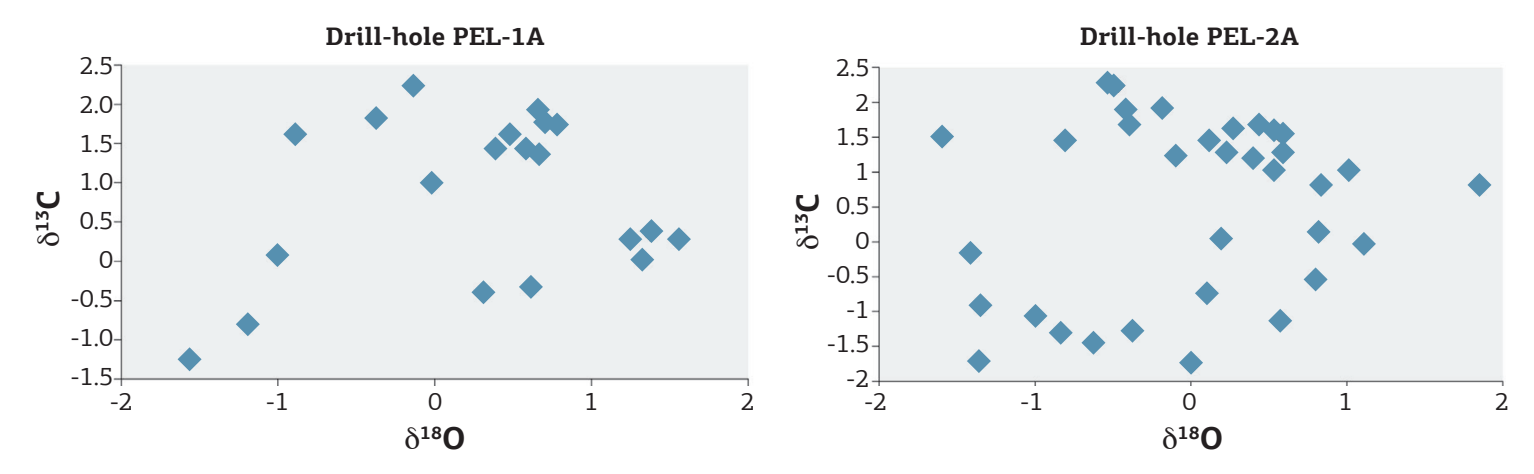

Figure 5. $\delta^{18} \mathrm{O}$ versus $\delta^{13} \mathrm{C}$ plots for the studied drill-holes.

event that promotes the reworking of the Miocene deposits by exposing areas of the platform. This matches the discontinuities including the Burdigalian section mentioned above.

In drill-holes PEL-1A and PEL-2A, foraminifera shells affected by cementation and neomorphism were found immediately below the interval containing coated shells, which forms the studied section's older interval. Recrystallization represents an important process of mineralogical stabilization in which a textural modification takes place due to the replacement of the shell's biogenic calcite by larger crystals. Degradation of the shell's original texture is caused by successive episodes of dissolution and re-precipitation, resulting in the complete replacement of the biogenic calcite by inorganic calcite (Pearson \& Burgess 2008). Recrystallization affects the shell's isotopic composition as the water in which the neomorphic calcite had been precipitated presents a distinct composition (Williams et al. 2005).

\section{Hiatuses and sedimentation rates}

Based on the ages obtained from ${ }^{87} \mathrm{Sr} /{ }^{86} \mathrm{Sr}$ ratios, it was possible to recognize eight hiatuses in the studied section: six in drill-hole PEL-2 and two in drill-hole PEL-1A (Fig. 4). The significance of these hiatuses is based on their correlation with events registered in adjacent basins.

The hiatus identified in the early Eocene section (Ypresian) spanning 5.9 Ma in drill-hole PEL-2A can be correlated to a discontinuity reported by Koutsoukos (1982) (ca. $47.2-51 \mathrm{Ma}$ ) in the basin northern portion.

The hiatus identified in the early Oligocene section (Rupelian) involving a time span of $1.73 \mathrm{Ma}$ can be related to the erosional unconformity and its correlative conformity reported by Contreras et al. (2010) that cover the interval between -30 and 33.9 Ma.

A gap was identified in drill-hole PEL-2A in the RupelianChattian interval spanning 2.41 Ma. In this same interval
Contreras et al. (2010) also indicated a discontinuity, which was interpreted as a maximum flooding surface. In this case, the hiatus corresponds to the record of a condensed section.

A hiatus between late Oligocene (Chattian) and the early Miocene (Aquitanian), which involves a time span of 1.75 $\mathrm{Ma}$, was recorded in drill-hole PEL-1A. This hiatus can be correlated with the unconformity identified by Anjos and Carreño (2004) between the late Oligocene and early Miocene in the northern portion of the Pelotas Basin, based on planktonic foraminifera biostratigraphy.

A disconformity identified between early and late Miocene (Burdigalian-Langhian) spanning 2.9 Ma in drill-hole PEL-1A and 1.21 Ma in drill-hole 2-RSS-1 can be related to the erosional event of Burdigalian age (ca. 17.4 Ma), named "Event E" that was registered in the southeastern portion of the Brazilian continental margin (Antunes 1989; Abreu \& Savini 1994). Furthermore, other authors (Vail \& Hardenbol 1979; Haq et al. 1988) have referred to a eustatic fall for this age.

Another hiatus was identified in the Miocene section in drill-hole PEL-2A. This major discontinuity between the middle and late Miocene (Langhian-Tortonian) spanning 3.54 Ma that involved the complete Serravalian stage and part of the Tortonian and Langhian stages can be related to a hiatus between middle and late Miocene $(-12-10 \mathrm{Ma})$ in the Pelotas Basin as proposed by Koutsoukos (1982) based on planktonic foraminifera biostratigraphy. Furthermore, an erosive surface in the late Miocene section of the Pelotas Basin (ca. $10 \mathrm{Ma}$ ) was reported by Fontana (1996). This hiatus was also reported in other basins of the Brazilian continental margin (e.g. Viana et al. 1990; Rossetti 2001; Pasley et al. 2004; Arai 2006), representing a horizon of interregional correlation in the basins of the Brazilian continental margin, caused as a consequence of a sea-level fall in the middle Miocene (Burdigalian-Serravalian). 
Up-section in the drill-hole PEL-2A, a hiatus was identified in the late Miocene section (Messinian-Tortonian), encompassing 2.95 Ma. A biostratigraphic study performed by Gomide (1989) indicated the absence of the nanofossils biozone N-630, of Tortonian age, in onshore wells drilled in the Pelotas Basin. This indicates an unconformity involving at least the inferior portion of the early Miocene section.

Sedimentary rates were calculated based on the strontium isotopic ratio curve of drill-hole PEL-2A, which has a major data density. The results are shown in Fig. 6. The hiatuses considered as unconformities are represented as gaps, as the lack of sedimentary section by probable sub-aerial erosion would induce a bias on the sedimentation rates. From the base of the studied section at $2,619 \mathrm{~m}(54.41 \mathrm{Ma})$ to $2,097 \mathrm{~m}(28.50$ $\mathrm{Ma})$ the sedimentation rates range from 18 to $51 \mathrm{~m} / 10^{6}$ years. Only a short interval around $47 \mathrm{Ma}$ presented higher rates (about $88 \mathrm{~m} / 10^{6}$ years). Despite the fact that the section is cut by some unconformities (Ypresian, Eocene-Oligocene, Rupelian), the sedimentation rates are kept constant and relatively low.

Between 2,079 and 2,043 m (28.00 - 25.25 Ma), sedimentation occurred at the lowest rates for the entire section (around $13 \mathrm{~m} / 10^{6}$ years). This interval probably contains the maximum flooding surface reported by Contreras et al. (2010) (Fig. 7).

The sedimentation rates abruptly increased up-section from 2,043 to $1,512 \mathrm{~m}(24.95-19.13 \mathrm{Ma})$; the background values were about $80 \mathrm{~m} / 10^{6}$ years. Two peaks of $385 \mathrm{~m} / 10^{6}$ years and $300 \mathrm{~m} / 10^{6}$ years were observed at the age intervals between 24.95 and 24.81 Ma and from 23.90 to $23.75 \mathrm{Ma}$, respectively. The rates decreased between 1,512 and $1,386 \mathrm{~m}$ $(19.13$ - $15.33 \mathrm{Ma})$, ranging from 29 to $37 \mathrm{~m} / 10^{6}$ years.

Above the middle-late Miocene unconformity the sedimentary rates reached the highest values for the entire section. Between 1,386 and 1,260 $\mathrm{m}(10.55-9.85 \mathrm{Ma})$ the rate was ca. $102 \mathrm{~m} / 10^{6}$ years. Between 1,260 and $1,098 \mathrm{~m}$ $(9.85-9.40 \mathrm{Ma})$ the rate reached $576 \mathrm{~m} / 10^{6}$ years. These high sedimentation rates can be related to the Rio Grande Cone, a coeval feature developed in the southern portion of the Pelotas Basin. The Rio Grande Cone has been interpreted as a clastic wedge developed under higher rates of continental denudation (Alves 1977). Studies of large structures such as the Rio Grande Cone and Amazon Cone point out the high sedimentation rate due to the higher sedimentation input from larger river systems in short periods. One of the best examples is the Amazon Fan, which is a sedimentary wedge containing thin-skinned structures with $10 \mathrm{~km}$ thickness and approximately $300 \mathrm{~km}$ long (Cobbold et al. 2004) with an average rate of up to $10,000 \mathrm{~m} / 10^{6}$ year (Flood \& Piper 1997). In the Rio Grande Cone more than $4 \mathrm{~km}$ of sediments were deposited in a restricted area of $28,900 \mathrm{~km}^{2}$ (Castillo-Lopez

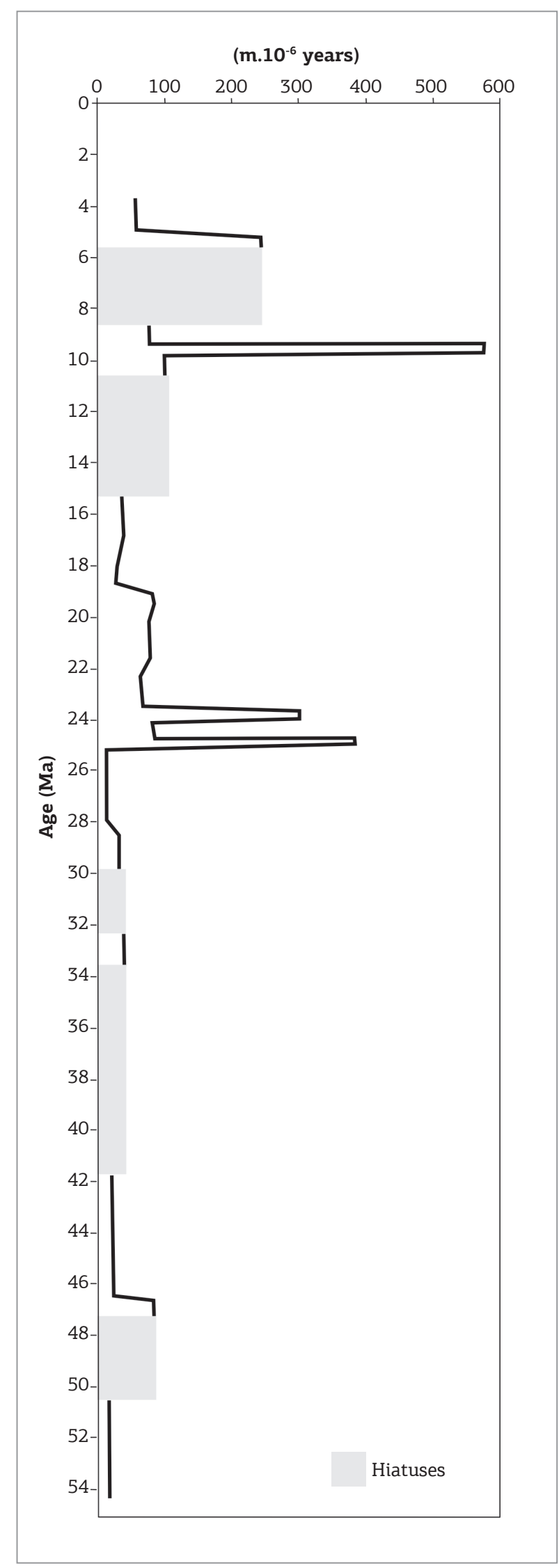

Figure 6. Sedimentation rates for drill-hole PEL-2A. 


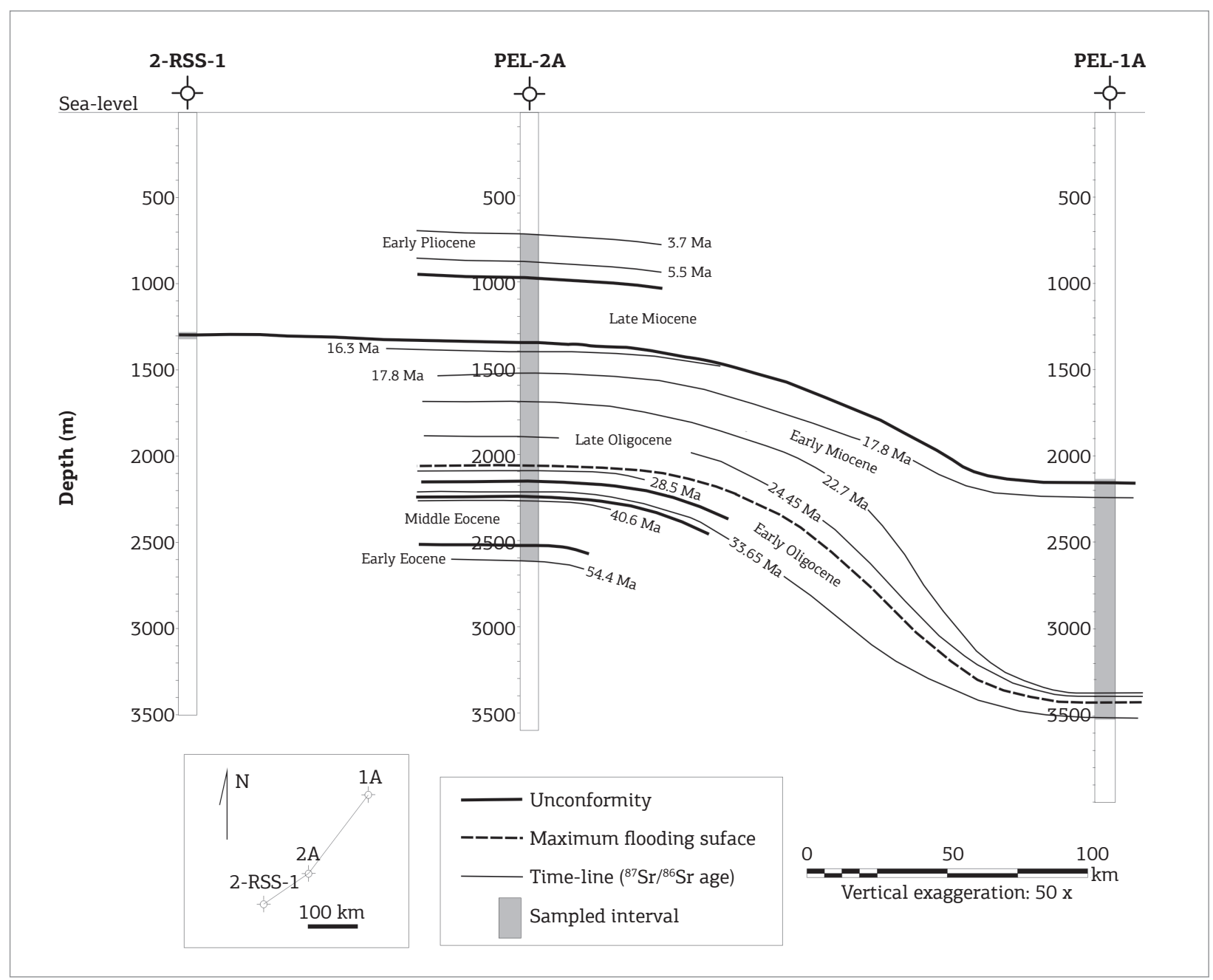

Figure 7. Cross-section through the studied drill-holes, showing the important horizons identified.

2008) and is located close to the analyzed drill holes; hence, the estimated sedimentation rate of $576 \mathrm{~m} / 10^{6}$ years during an interval of hundred thousand years in the upper Miocene is quite reasonable for the studied area.

Between 1,098 and $990 \mathrm{~m}(9.40-8.65 \mathrm{Ma})$ the sedimentation rates had diminished to around $77 \mathrm{~m} / 10^{6}$ years. Above the Tortonian-Messinian unconformity (between 990 and $828 \mathrm{~m}, 5.65-5.25 \mathrm{Ma}$ ) the rates increased again, ca. $231 \mathrm{~m} / 100$ years. The rates dropped to about $58 \mathrm{~m} / 10^{6}$ years between 828 and $720 \mathrm{~m}(5.25-3.70 \mathrm{Ma})$.

\section{Thermal events and paleoproductivity}

Based on oxygen and carbon isotope ratio data from the early Oligocene to late Miocene of drill-hole PEL-2A, it was possible to recognize paleotemperature trends and variations in productivity throughout the studied interval.

From the early Oligocene to late Miocene (Burdigalian) a progressive lowering of $\delta^{18} \mathrm{O}$ indicates a period of gradual warming, culminating at $19.13 \mathrm{Ma}$, with a minimum $\delta^{18} \mathrm{O}$ value of $-3.37 \%$ (Fig. 8). This event is consistent with reports of a warming trend through late Oligocene to early Miocene (Savin et al. 1981; Hodell \& Kennett 1985; Spezzaferri 1995).

From the early Miocene (Burdigalian, $19.13 \mathrm{Ma}$ ) to middle Miocene (Langhian, $14.97 \mathrm{Ma}$ ) a positive $\delta^{18} \mathrm{O}$ excursion tends to suggest a recrystallization effect caused by the preferential removal of the ${ }^{16} \mathrm{O}$ (Killingley 1983; Williams et al. 2005). This oxygen shift is supposed to be caused by a diagenetic process as the interval between ca. 17 and $15 \mathrm{Ma}$ represents a global warm period characterized as the middle Miocene Climatic Optimum (Zachos et al. 2001). Additionally, neomorphism features were frequently observed in the shells recovered from this interval. As recrystallization can occur in micrometric scale, poorly preserved shells might have been selected, which might have influenced the stable isotope analyses.

The interval between 14.97 Ma (Langhian) and 10.4 Ma (Tortonian) was poorly sampled, precluding a consistent interpretation. 


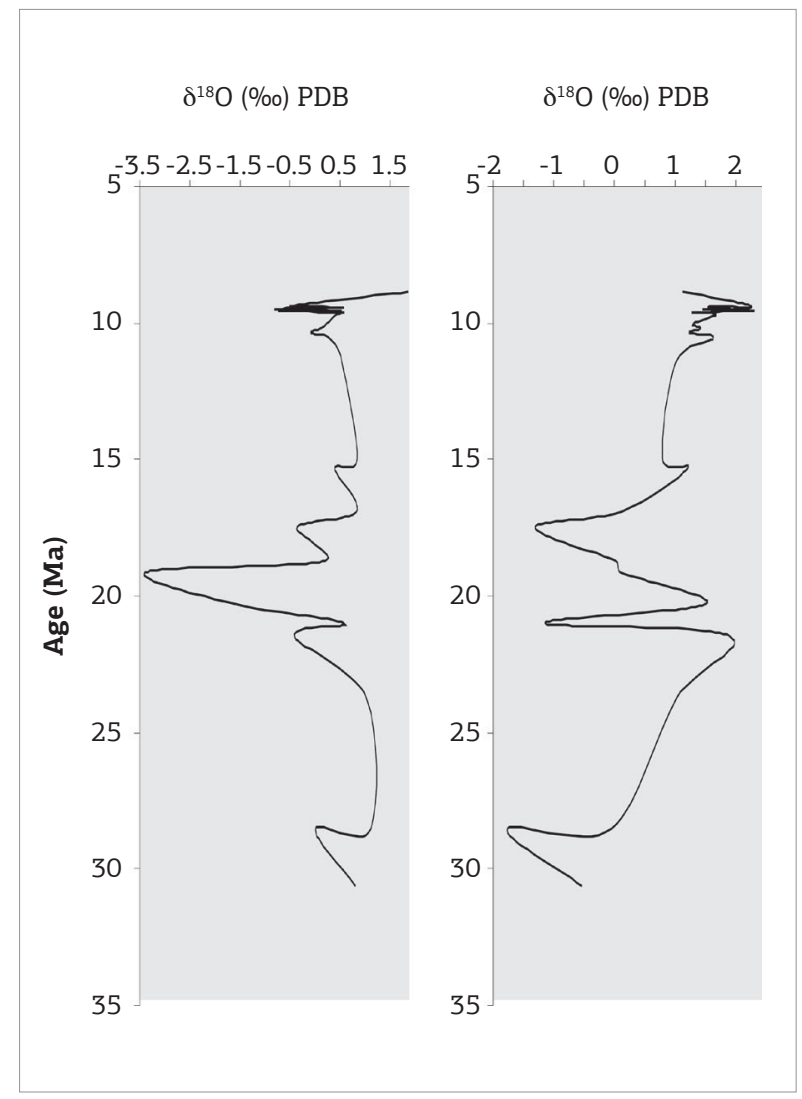

Figure 8. $\delta^{18} \mathrm{O}$ and $\delta^{13} \mathrm{C}$ data versus age for drill-hole PEL-2A.

In the late Miocene, from 10.4 Ma (Tortonian) to 6.93 Ma (Messinian) a major cooling trend was interpreted based on a $\delta^{18} \mathrm{O}$ positive excursion (Fig. 8). This temperature decline is coherent with the paleoclimatic scenario of the late Miocene, which was characterized by worldwide cooling and ice-sheet growth in Antarctica (Zachos et al. 2001; Billups 2002). In addition, the beginning of this cooling trend matched exactly the glaciation event Mi-6 of Miller et al. (1991), the age that was astronomically calibrated by Turco et al. (2001).

$\mathrm{A} \delta^{13} \mathrm{C}$ positive excursion between Rupelian (28.16 Ma) and Aquitanian $(21.44 \mathrm{Ma}$ ) indicate a gradual increase in the productivity or the burial of organic matter. This trend can be related, although slightly out-of-phase, to the above-mentioned warming event as milder climates promoted enhanced weathering of the continental rocks and, consequently, increase in nutrient influx and productivity. A carbon isotope ratio positive excursion at late Oligocene to early Miocene $(24.4-22.6 \mathrm{Ma})$ was reported by Hodell and Woodruff (1994), and was called "carbon isotopic maximum at Oligocene-Miocene boundary". This event has been recognized by other authors such as Zachos et al. (2001), Zhao et al. (2001) and Mutti et al. (2005).

\section{CONCLUSIONS}

Integration of the chronostratigraphic data generated in this study with biostratigraphic data compiled from the literature provides elements to refine the chronostratigraphic framework of Tertiary section of the Pelotas Basin.

The recognition of hiatuses that match those based on biostratigraphic data, as well as with global events, demonstrates the quality of the isotope data obtained. Strontium isotope relative ages represent an alternative method to biostratigraphy with high-quality data, although the application of both methods and the comparison of the results are highly recommended.

The use of ${ }^{87} \mathrm{Sr} /{ }^{86} \mathrm{Sr}$ ratios enabled the identification of six hiatuses in the studied section of the drill-hole PEL-2A: (i) early Eocene, (ii) late Eocene to early Oligocene, (iii) early Oligocene, (iv) early-late Oligocene boundary, (v) middlelate Miocene, and (vi) late Miocene (eight discontinuities in the studied drill-holes). Two of them were observed in the studied section of the drill-hole PEL-1A: (i) late Oligocene to early Miocene and (ii) between early-middle Miocene. A hiatus in the early Miocene section was recognized in the drill-hole 2-RSS-1. The ages obtained from the drill-hole 2-RSS-1 indicate a hiatus in the early Miocene.

The early-late Oligocene hiatus is considered a maximum flooding surface. The other hiatuses identified are related to unconformities. The very high sedimentation rate estimated for the Upper Miocene Section is linked to the formation of the 4,000-m thick Rio Grande Cone structure situated in close proximity to the analyzed drill holes.

Isotopic data $\left(\delta^{13} \mathrm{C}\right.$ and $\left.\delta^{18} \mathrm{O}\right)$ from the early Oligocene to the late Miocene section from drill-hole PEL-2A support the identification of a global warming trend.

\section{ACKNOWLEDGMENTS}

The authors acknowledge Petrobras (Petróleo Brasileiro S.A.) for supplying the samples, the Project FINEP-CTPETRO (project number 6500.0026.00) for financial support to sample analyses, and the Brazilian National Petroleum Agency (ANP) for the grant to G. S. Anjos-Zerfass. We acknowledge Rene Rodrigues and Ricardo Latgé for the logistic support provided for this project. Thanks to J. M. McArthur (UCL) for providing the strontium lookup table for deriving numerical age. We would like to express our gratitude to H. Zerfass, R. Pietzsch Amora, and S. Shimabukuro (Petrobras) for the comments and suggestions and to A. B. Oliveira (UFS) for assistance with chemical data treatment. We are also in debt to the reviewers for their constructive criticisms and comments that contributed to improve this work. 


\section{REFERENCES}

Abreu V.S. 1998. Geologic evolution of conjugate volcanic passive margins: Pelotas Basin (Brazil) and offshore Namibia (Africa): implication for global sea-level changes, Ph.D. thesis, Rice University, $710 \mathrm{p}$.

Abreu V.S. \& Savini R.R. 1994. Major paleoceanographic events of the Brazilian continental margin: relationships with the giant oil fields of the Oligo-Miocene of Campos Basin, Brazil. In: $26^{\text {th }}$ Annual Offshore Technology Conference, Houston, Texas, p. 335-344.

Alves E.C. 1977. Estrutura rasa do Talude e Sopé da Margem Continental do Rio Grande do Sul e Uruguai. MS Dissertation, Instituto de Geociências, Universidade Federal do Rio Grande do Sul, $74 \mathrm{p}$.

Anjos G.S. \& Carreño A.L. 2004. Bioestratigrafia (Foraminiferida) da sondagem 1-SCS-3B, Plataforma de Florianópolis, Bacia de Pelotas. Revista Brasileira de Paleontologia, 7(2):127-138.

Anjos-Zerfass G.S., Chemale Jr. F., Moura C.A.V. 2011. Postdepositional effects on the microstructure and stable isotopes composition of planktic foraminiferal tests from the Miocene of the Pelotas Basin, South Brazilian Continental Margin. Revista Mexicana de Ciências Geológicas, 28:92-104.

Antunes R.L. 1989. Cenozoic erosive events in central-northern portion of the Santos Basin-Brazil: A biochronoestratigraphical study based on calcareous nannofossils. In: SBP, Congresso Brasileiro de Paleontologia, 21, Anais, p. 1043-1058.

Arai M. 2006. A grande elevação eustática do Mioceno e sua influência na origem do Grupo Barreiras. Revista do Instituto de Geociências-USP, $6(2): 1-6$.

Billups K. 2002. Late Miocene through early Pliocene deep water circulation and climate change viewed from the subantarctic Southern Ocean. Palaeoecology, Palaeogeography, Palaeoclimatology, 185:287-307.

Brown S.J. \& Elderfield H. 1996. Variations in the $\mathrm{Mg} / \mathrm{Ca}$ and $\mathrm{Sr} /$ Ca ratios of planktonic foraminifera caused by postdepositional dissolution: Evidence of shallow Mg-dependent dissolution. Paleoceanography, 11(5):543-551.

Bueno G.V., Zacharias A.A., Oeiro S.G., Cupertino J.A., Falkenhein F.U.H., Martins Neto M.A. 2007. Bacia de Pelotas. Boletim de Geociências da Petrobras, 15(2):551-559.

Castillo-López L.A. 2008. Interpretação sismoestratigráfica e geomorfologia sísmica do Cone de Rio Grande, Bacia de Pelotas, PhD Thesis, Instituto de Geociências, Universidade Federal do Rio Grande do Sul, 159 p.

Castillo-López L.A., Kazmierczak T.S., Chemale F. 2009. Rio Grande Cone tectono-stratigraphic model - Brazil: Seismic sequences. Earth Science Research Journal, 13(1):40-53.

Cobbold P.R., Mourgues R., Boyd K. 2004. Mechanism of thinskinned detachment in the Amazon Fan: Assessing the importance of fluid overpressure and hydrocarbon generation. Marine Petroleum Geology, 21:1013-1025.

Coimbra J.C., Carreño A.L., Anjos-Zerfass G.S. 2009. Biostratigraphy and paleoceanographical significance of the Neogene planktonic foraminifera from the Pelotas Basin, southernmost Brazil. Revue de Micropaléontologie, 52:1-14.

Collen J.D. \& Burgess C.J. 1979. Calcite dissolution, overgrowth and recrystallization in the benthic foraminiferal genus Notorotalia. Journal of Paleontology, 53(6):1343-1353.
Contreras J., Zühlke R., Bowman S., Bechstädt T. 2010. Seismic stratigraphy and subsidence analysis of the southern Brazilian margin (Campos, Santos and Pelotas basins). Marine and Petroleum Geology, 27:1952-1980.

Depaolo D.J. \& Finger K.L. 1991. High-resolution strontiumisotope stratigraphy and biostratigraphy of the Miocene Montery Formation, Central California. Geological Society of America Bulletin, 103(1):112-124.

Dias J.L., Silveira D.P., Sad A.R.E., Latgé M.A.L. 1994. Bacia de Pelotas: Estágio atual do conhecimento geológico. Boletim de Geociências da Petrobras, 8(1):235-245.

Ehrenberg S.N., Pickard N.A.H., Laursen G.V., Monibi S., Mossadegh Z.K., Svånå T.A., Aqrawi A.A.M., McArthur J.M., Thirlwall M.F. 2007. Strontium isotope strastigraphy of the Asmari Formation (Oligocene-Lower Miocene), SW Iran. Journal of Petroleum Geology, 30(2):107-128.

Elderfield H. 1986. Strontium isotope stratigraphy. Palaeogeography, Palaeoclimatology, Palaeoecology, 57:71-90.

Flood R.D. \& Piper D.J.W. 1997. Amazon Fan sedimentation: The relationship to Equatorial climate change, continental denudation, and sea-level fluctuations. In: R.D. Flood, D.J.W. Piper, A. Klaus \& L.C. Peterson (eds.). Proceedings of the Ocean Drilling Program, Scientific Results, 155:653-675.

Fontana R.L. 1987. Desenvolvimento termomecânico da Bacia de Pelotas e parte sul da Plataforma de Florianópolis. Instituto de Geociências, MS Dissertation, Instituto de Geociências, Universidade Federal de Ouro Preto, 128 p.

Fontana R.L. 1990. Investigações geofísicas preliminares sobre o Cone do Rio Grande, Bacia de Pelotas, Brasil. Acta Geológica Leopoldensia, 13(6):161-170.

Fontana R.L. 1996. Geotectônica e sismoestratigrafia da Bacia de Pelotas e Plataforma de Florianópolis. Tese de Doutorado, Instituto de Geociências, Universidade Federal do Rio Grande do Sul, $214 \mathrm{p}$.

Gomide J. 1989. Bacia de Pelotas - Biocronoestratigrafia baseada em nanofósseis calcários. In: SBP, Congresso Brasileiro de Paleontologia, 11, Anais, p. 338-351.

Guerra R.M., Tokutake L.R., Fauth G. 2012. Cretaceous calcareous nannofossils from Pelotas Basin, Brazil: Biostratigraphic and paleoecological inferences. Journal of South American Earth Sciences, 36:55-71.

Hall J.M. \& Chang L.H. 2004. Li/Ca in multiple species of benthic and planktonic foraminifera: Thermocline, latitudinal, and glacial-interglacial variation. Geochimica et Cosmochimica Acta, 68(3):529-545.

Hampt G. \& Delaney M.L. 1997. Influences on calcite Sr/Ca records from Ceara Rise and other regions: Distinguishing ocean history and calcite neomorphism. In: N.J. Shackleton, W.B. Curry, C. Richter \& T.J. Bralower (eds.). Proceeding of the Ocean Drilling Project, Scientific Results, 154:491-500.

Haq B.U., Hardenbol J., Vail P.R. 1988. Mesozoic and Cenozoic chronostratigraphy and cycles of sea-level change. Society of Economic Paleontologists and Mineralogists Special Publication, 42:71-108.

Hess J., Bender M.L., Schilling J. 1986. Evolution of the ratio of strontium 87 to strontium 86 in seawater from Cretaceous to Present. Science, 231:979-984. 
Hodell D.A., Mueller P.A., Garrido J.R. 1991. Variation in the strontium isotope composition of the seawater during the Neogene. Geology, 19:24-27.

Hodell D.A. \& Kennett J.P. 1985. Miocene paleoceanography of the South Atlantic Ocean at 22, 16 and 8 Ma. In: J.P. Kennett (ed.), 1985. The Miocene ocean: Paleoceanography and Biogeography. Geological Society of America Memoir, 163:317-337.

Hodell D.A. \& Woodruff F. 1994. Variations in the strontium isotopic ratio of seawater during the Miocene: Stratigraphic and geochemical implications. Paleoceanography, 9(3):405-426.

Killingley J.S. 1983. Effects of diagenetic recrystallization on ${ }^{18} \mathrm{O} / 16 \mathrm{O}$ values of deep-sea sediments. Nature, 301:594-597.

Koutsoukos E.A.M. 1982. Geohistória e paleoecologia das bacias marginais de Florianópolis e Santos. In: SBG, Congresso Brasileiro de Geologia, 32, Anais, p. 2369-2382.

Kowsmann R.O., Francisconi O., Leyden R. 1974. Refração sísmica marinha nas bacias de Pelotas, Santos Sul e na Plataforma de Torres. In: SBG, Congresso Brasileiro de Geologia, 28, Anais, p. 283-295.

Lavelle M. 2000. Strontium isotope stratigraphy and age model for CRP-2/2A, Victoria Land Basin, Antarctica. Terra Antartica, 7(4):611-619.

Lea D.W., Mashiotta T.A., Spero H. 1999. Controls on magnesium and strontium uptake in planktonic foraminifera determined by live culturing. Geochimica et Cosmochimica Acta, 63(16):2369-2379.

Lear C.H., Elderfield H., Wilson P.A. 2003. A Cenozoic seawater Sr/ Ca record from benthic foraminiferal calcite and its application in determining global weathering fluxes. Earth and Planetary Science Letters, 208:69-84.

Lohmann G.P. 1995. A model for variation in the chemistry of planktonic foraminifera due to secondary calcification and selective dissolution. Paleoceanography, 10(3):445-457.

McArthur J.M. \& Howarth R.J. 2004. Strontium isotope stratigraphy. In: A Geological Timescale 2004, Gradstein F.M., Ogg J.G. \& Smith A.G. (eds.), Cambridge, CUP, p. 96-105.

McArthur J.M., Howarth R.J., Bailey T.R. 2001. Strontium isotope stratigraphy: LOWESS Version 3. Best-fit line to the marine Srisotope curve for 0 to $509 \mathrm{Ma}$ and accompanying look-up table for deriving numerical age. Journal of Geology, 109:155-169.

Miller K.G., Wright J.D., Fairbanks R.G. 1991. Unlocking the ice house: Oligocene-Miocene oxygen isotopes, eustasy and margin erosion. Journal of Geophysical Research, 96(b4):6829-6848.

Mutti M., Droxler A.W., Cunningham A.D. 2005. Evolution of the Northern Nicaragua Rise during the Oligocene-Miocene: Drowning by environmental factors. Sedimentary Geology, 175:237-258.

Nier A.O. 1938. The isotopic constitution of strontium, barium, bismuth, thallium, and mercury. Physical Review, 54:275-278,

Oslick J.S., Miller K.G., Feigenson M.D., Wright J.D. 1994 Oligocene-Miocene strontium isotopes: Stratigraphic revisions and correlation to an inferred glacioeustatic record. Paleoceanography, 9:427-444.

Parras A., Dix G.R., Griffin M. 2012. Sr-isotope chronostratigraphy of Paleogene-Neogene marine deposits: Austral Basin, southern Patagonia (Argentina). Journal of South American Earth Sciences, 37:122-135.

Pasley M.A., Shepherd D.B., Pocknall D.T., Boyd K.P., Andrade V., Figueiredo J.P. 2004. Sequence stratigraphy and Basin evolution of the Foz do Amazonas Basin, Brazil. In: American Association of Petroleum Geologists, AAPG International Conference and Exhibition, Extended Abstract Volume, $12 \mathrm{p}$.

Pearson P.N. \& Burgess C.E. 2008. Foraminifer shell preservation and diagenesis: Comparison of high latitude controls on the paleoceanographic environmental proxies. Geological Society Special Publication, 303:59-72.

Pearson P.N., Ditchfield P.W., Singano J., Harcourt-Brown K.G., Nicholas C.J., Olsson R.K., Shackleton N.J., Hall M. 2001. Warm tropical sea surface temperatures in the Late Cretaceous and Eocene epochs. Nature, 413:481-487.

Rosa A.P. 2007. Interpretação sismo-estratigráfica da porção da Bacia de Pelotas que engloba o Cone do Rio Grande e a avaliação do seu potencial petrolífero. Tese de doutorado, Instituto de Geociências, Universidade Estadual do Norte Fluminense, $121 \mathrm{p}$

Rossetti D.F. 2001. Late Cenozoic sedimentary evolution in northerneastern Pará, Brazil, within the context of sea level changes. Journal of South American Earth Sciences, 14:77-89.

Savin S.M. \& Douglas R.G. 1973. Stable isotope and magnesium geochemistry of recent planktonic foraminifera from South Pacific. Geological Society of America Bulletin, 84(7):2327-2342.

Savin S.M., Douglas R.G., Keller G., Killingley J.S., Shaughnessy L., Sommer M.A., Vincent E., Woodruff F. 1981. Miocene benthic foraminiferal isotope records: A synthesis. Marine Micropaleontology, 6:423-450

Scholle P.A. \& Arthur M.A. 1980. Carbon isotope fluctuations in cretaceous pelagic limestones: Potential stratigraphic and petroleum exploration tool. American Association of Petroleum Geologists Bulletin, 64(1):67-87.

Sexton P.F., Wilson P.A., Pearson P.N. 2006. Microstructural and geochemical perspectives on planktic foraminiferal preservation: "glassy" versus "frosty". Geochemistry, Geophysics, Geosystems, 7(Q12P19)

Shieh Y.T., You C.F., Shea K.S., Horng C.S. 2002. Identification of artifacts in foraminiferal shells using carbon and oxygen isotopes. Journal of Asian Earth Sciences, 21:1-5.

Spezzaferri S. 1995. Planktonic foraminiferal implications across the Oligocene-Miocene transition in the oceanic record (Atlantic, Indian and South Pacific). Palaeogeography, Palaeoclimatology, Palaeoecology, 114:48-74.

Stica M.J., Zalán P.V., Ferrari A.L. 2014. The evolution of rifting on the volcanic margin of the Pelotas Basin and the contextualization of the Paraná-Etendeka LIP in the separation of Gondwana in the South Atlantic. Marine and Petroleum Geology, 50:1-21.

Sugarman P.J., Miller K.G., Owens J.P., Feigenson M.D. 1993 Strontium-isotope and sequence stratigraphy of the Miocene Kirkwood Formation, Southern New Jersey. Geological Society of America Bulletin, 105(4):423-436

Turco E., Hilgen F.J., Lourens L.J., Shackleton N.J., Zachariasse W.J. 2001. Punctuated evolution of global climate cooling during the late Middle to early Late Miocene: High-resolution planktonic foraminiferal and oxygen isotope records from the Mediterranean. Paleoceanography, 16(4):405- 423.

Vail P.R. \& Hardenbol J. 1979. Sea level changes during Tertiary. Oceanus, 22(3):71-79.

Veizer J., Ala D., Azmy K., Bruckschen P., Bruhn F., Buhl D., Carden G., Diener A., Ebneth S., Goddris Y., Jasper T., Korte C., Pawellek F., Podlaha O., Strauss H. 1999. ${ }^{87} \mathrm{Sr} /{ }^{86} \mathrm{Sr}, \delta^{18} \mathrm{O}$ and $\delta^{13} \mathrm{C}$ Evolution of Phanerozoic seawater. Chemical Geology, 161:59-88. 
Viana A.R., Castro D.D., Kowsmann R.O. 1990. A discordância do Mioceno médio superior um marco regional no talude da Bacia de Campos. In: SBG, Congresso Brasileiro de Geologia, 36, Anais, p. 313-333.

Zachos J., Pagani M., Sloan L., Thomas E., Billups K. 2001. Trends, rythms, and aberrations in global climate $65 \mathrm{Ma}$ to present. Science, 292:686-693.

Zhao Q., Wang P., Cheng X., Wang J., Huang B., Xu J., Zhou Z., Jian Z. 2001. A record of carbon excursions in the South China Sea. Science in China (Series D), 44(10):943-951.
Williams M., Haywood A.M., Taylor S.P., Valdes P.J., Sallwood B.W., Hillenbrand C.D. 2005. Evaluating the efficacy of planktonic foraminifer calcite $\delta^{18} \mathrm{O}$ data for sea surface temperature reconstruction for the Late Miocene. Geobios, 38:843-863.

Williams M., Haywood A.M., Vautravers M., Sellwood B.W., Hillenbrand C.D., Wilkinson I.P.A., Miller C.G. 2007. Relative effect of taphonomy on calcification temperature estimates from fossil planktonic foraminifera. Geobios, 40:861-874.

$\overline{\text { Arquivo digital disponível on-line no site www.sbgeo.org.br }}$ 
Appendix 1. Drill-hole PEL-2A ${ }^{87} \mathrm{Sr} /{ }^{86} \mathrm{Sr}$ ratio data and the corresponding ages

\begin{tabular}{|c|c|c|c|c|c|c|c|c|c|c|c|c|c|c|}
\hline $\begin{array}{l}\text { E् } \\
\text { 至 } \\
\text { 苋 }\end{array}$ & 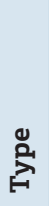 & 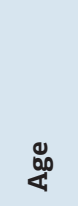 & 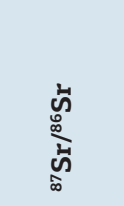 & 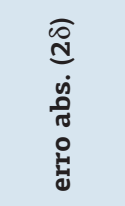 & 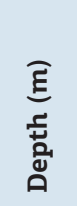 & $\underset{\mathrm{E}}{\stackrel{\Delta}{\mathrm{H}}}$ & 品 & 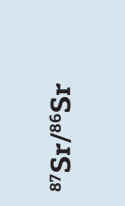 & 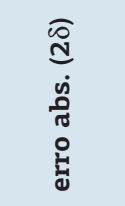 & 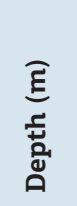 & 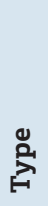 & 品 & 峁 & 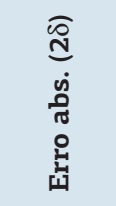 \\
\hline 720 & $\mathrm{P}$ & 3.70 & 0.708489 & 0.000058 & 1,314 & $\mathrm{P}$ & 10.35 & 0.708935 & 0.000013 & 2,061 & B & 25.60 & 0.707711 & 0.000014 \\
\hline 720 & B & 3.70 & 0.708606 & 0.000042 & 1,332 & $\mathrm{~B}$ & 10.55 & 0.708869 & 0.000013 & 2,079 & B & 28.00 & 0.707938 & 0.000014 \\
\hline 738 & $\mathrm{P}$ & 4.01 & 0.709209 & 0.000032 & 1,350 & $\mathrm{~B}$ & 11.40 & 0.708846 & 0.000013 & 2,097 & B & 28.50 & 0.708039 & 0.000014 \\
\hline 738 & B & 4.01 & 0.709034 & 0.000015 & 1,368 & $\mathrm{~B}$ & 14.97 & 0.708687 & 0.000017 & 2,115 & B & 28.51 & 0.707679 & 0.000012 \\
\hline 756 & B & 4.32 & 0.708837 & 0.000017 & 1,386 & $\mathrm{~B}$ & 15.33 & 0.708691 & 0.000017 & 2,133 & B & 28.52 & 0.708039 & 0.000012 \\
\hline 786 & B & 4.63 & 0.708939 & 0.000015 & 1,404 & $\mathrm{P}$ & 15.79 & 0.708734 & 0.000015 & 2,151 & B & 29.10 & 0.708016 & 0.000012 \\
\hline 792 & B & 4.94 & 0.708934 & 0.000018 & 1,422 & $\mathrm{~B}$ & 16.30 & 0.708472 & 0.000014 & 2,169 & B & 29.87 & 0.707752 & 0.000012 \\
\hline 828 & B & 5.25 & 0.709028 & 0.000013 & 1,440 & $\mathrm{~B}$ & 16.90 & 0.708488 & 0.000014 & 2,187 & B & 30.65 & 0.707961 & 0.000011 \\
\hline 882 & B & 5.50 & 0.709021 & 0.000013 & 1,458 & $\mathrm{~B}$ & 17.50 & 0.708509 & 0.000039 & 2,205 & B & 32.38 & 0.707898 & 0.000014 \\
\hline 900 & B & 5.55 & 0.708807 & 0.000015 & 1,458 & B & 18.10 & 0.708311 & 0.000018 & 2,223 & $\mathrm{P}$ & 33.01 & 0.708136 & 0.000011 \\
\hline 936 & $\mathrm{P}$ & 5.6 & 0.709087 & 0.000013 & 1,476 & $\mathrm{~B}$ & 18.72 & 0.708532 & 0.000012 & 2,259 & B & 33.65 & 0.707826 & 0.000012 \\
\hline 972 & B & 5.65 & 0.709059 & 0.000014 & 1,512 & $\mathrm{P}$ & 19.13 & 0.708374 & 0.000014 & 2,277 & B & 40.6 & 0.707069 & 0.000012 \\
\hline 978 & B & 5.70 & 0.709011 & 0.000014 & 1,548 & B & 19.55 & 0.708468 & 0.000014 & 2,295 & $\mathrm{P}$ & 41.78 & 0.707878 & 0.000014 \\
\hline 990 & B & 8.65 & 0.708924 & 0.000014 & 1,566 & $\mathrm{P}$ & 20.28 & 0.708247 & 0.000012 & 2,331 & B & 42.95 & 0.707789 & 0.000011 \\
\hline 1,008 & B & 8.85 & 0.708967 & 0.000035 & 1,602 & $\mathrm{P}$ & 21.01 & 0.708384 & 0.000011 & 2,367 & $\mathrm{P}$ & 44.13 & 0.707893 & 0.000012 \\
\hline 1,026 & B & 9.15 & 0.709067 & 0.000019 & 1,620 & B & 21.22 & 0.70827 & 0.000018 & 2403 & B & 45.30 & 0.70777 & 0.000017 \\
\hline 1,044 & B & 9.35 & 0.708909 & 0.000015 & 1,638 & $\mathrm{P}$ & 21.44 & 0.708467 & 0.000014 & 2,411 & B & 46.48 & 0.70781 & 0.000012 \\
\hline 1,098 & $\mathrm{P}$ & 9.40 & 0.708906 & 0.000017 & 1,674 & B & 21.65 & 0.708342 & 0.000012 & 2,421 & $\mathrm{~B}$ & 46.69 & 0.707872 & 0.000012 \\
\hline 1,116 & $\mathrm{P}$ & 9.42 & 0.708952 & 0.000019 & 1,692 & B & 22.30 & 0.708259 & 0.000012 & 2,439 & B & 46.89 & 0.707807 & 0.000014 \\
\hline 1,134 & B & 9.45 & 0.708905 & 0.000022 & 1,728 & B & 22.95 & 0.708477 & 0.000011 & 2,457 & B & 47.10 & 0.708095 & 0.000014 \\
\hline 1,134 & B & 9.45 & 0.708834 & 0.000024 & 1,782 & B & 23.60 & 0.708223 & 0.000011 & 2,475 & B & 47.30 & 0.707896 & 0.000011 \\
\hline 1,152 & $\mathrm{P}$ & 9.48 & 0.708916 & 0.000026 & 1,818 & B & 23.75 & 0.708319 & 0.000012 & 2529 & $\mathrm{~B}$ & 48.88 & 0.707810 & 0.000012 \\
\hline 1,170 & B & 9.51 & 0.708906 & 0.000017 & 1,863 & B & 23.90 & 0.708207 & 0.000014 & 2,547 & B & 50.47 & 0.707802 & 0.000011 \\
\hline 1,188 & $\mathrm{P}$ & 9.54 & 0.708950 & 0.000019 & 1,899 & B & 24.32 & 0.708306 & 0.000012 & 2,601 & B & 52.44 & 0.707819 & 0.000012 \\
\hline 1,206 & $\mathrm{P}$ & 9.57 & 0.708931 & 0.000021 & 1,917 & $\mathrm{~B}$ & 25.53 & 0.707922 & 0.000014 & 2,619 & $\mathrm{~B}$ & 54.41 & 0.707849 & 0.000012 \\
\hline 1,224 & $\mathrm{P}$ & 9.60 & 0.708921 & 0.000014 & 1,935 & $\mathrm{~B}$ & 24.75 & 0.708163 & 0.000011 & & & & & \\
\hline 1,242 & $\mathrm{P}$ & 9.65 & 0.708899 & 0.000014 & 1,953 & $\mathrm{~B}$ & 24.81 & 0.707606 & 0.000012 & & & & & \\
\hline 1,260 & B & 9.85 & 0.708892 & 0.000017 & 1,971 & B & 24.87 & 0.707693 & 0.000014 & & & & & \\
\hline 1,278 & $\mathrm{P}$ & 10.00 & 0.708914 & 0.000014 & 2,007 & B & 24.95 & 0.708155 & 0.000011 & & & & & \\
\hline 1,296 & $\mathrm{P}$ & 10.20 & 0.708951 & 0.000014 & 2,043 & B & 25.25 & 0.707960 & 0.000011 & & & & & \\
\hline
\end{tabular}

$\mathrm{B}=$ benthic foraminifera; $\mathrm{P}=$ Planktic foraminifera 
Appendix 2. Drill-holes PEL-1A and 2-RSS-1 ${ }^{87} \mathrm{Sr} /{ }^{86} \mathrm{Sr}$ ratio data and the corresponding ages.

\begin{tabular}{|c|c|c|c|c|c|}
\hline Drill-hole & Depth (m) & Type & Age & ${ }^{87} \mathrm{Sr} /{ }^{86} \mathrm{Sr}$ & Erro abs. $(2 \delta)$ \\
\hline PEL-1A & 2,142 & B & 14.9 & 0.708785 & 0.000128 \\
\hline PEL-1A & 2,178 & B & 17.8 & 0.708607 & 0.000113 \\
\hline PEL-1A & 2,268 & $\mathrm{P}$ & 18.5 & 0.708548 & 0.000128 \\
\hline PEL-1A & 2,304 & $\mathrm{P}$ & 18.9 & 0.708518 & 0.000128 \\
\hline PEL-1A & 2,448 & $\mathrm{P}$ & 19.9 & 0.708525 & 0.000128 \\
\hline PEL-1A & 2,736 & $\mathrm{P}$ & 20.9 & 0.708393 & 0.000128 \\
\hline PEL-1A & 2,844 & $\mathrm{P}$ & 22.9 & 0.708263 & 0.000127 \\
\hline PEL-1A & 2,988 & $\mathrm{P}$ & 21.1 & 0.708384 & 0.000016 \\
\hline PEL-1A & 3,132 & M & 20.3 & 0.70842 & 0.000128 \\
\hline PEL-1A & 3,168 & B & 20.15 & 0.708432 & 0.000014 \\
\hline PEL-1A & 3,186 & $\mathrm{P}$ & 21.05 & 0.708384 & 0.000014 \\
\hline PEL-1A & 3,258 & $\mathrm{P}$ & 21.5 & 0.708345 & 0.000014 \\
\hline PEL-1A & 3,276 & $\mathrm{P}$ & 21.4 & 0.708362 & 0.000128 \\
\hline PEL-1A & 3,312 & $\mathrm{P}$ & 21.8 & 0.708328 & 0.000014 \\
\hline PEL-1A & 3,384 & $\mathrm{P}$ & 22.7 & 0.708274 & 0.000127 \\
\hline PEL-1A & 3,402 & $\mathrm{P}$ & 24.45 & 0.708177 & 0.000113 \\
\hline PEL-1A & 3,492 & $\mathrm{P}$ & 32.9 & 0.707869 & 0.000014 \\
\hline PEL-1A & 3,510 & $\mathrm{P}$ & 34.15 & 0.708011 & 0.000014 \\
\hline PEL-1A & 3,528 & $\mathrm{P}$ & 32.15 & 0.707913 & 0.000020 \\
\hline PEL-1A & 3,582 & $\mathrm{P}$ & 30.95 & 0.707949 & 0.000016 \\
\hline PEL-1A & 3,708 & $\mathrm{P}$ & 34.4 & 0.707793 & 0.000016 \\
\hline 2-RSS-1 & 1,300 & B & 15.28 & 0,708766 & 0.000050 \\
\hline 2-RSS-1 & $1,303.6$ & B & 16.5 & 0,708689 & 0.000028 \\
\hline 2-RSS-1 & $1,304.05$ & B & 16.6 & 0,708697 & 0.000050 \\
\hline
\end{tabular}

$\mathrm{B}=$ benthic foraminifera; $\mathrm{P}=$ Planktic foraminifera; $\mathrm{M}=$ mixed benthic and planktic foraminifera. 